\title{
A REVIEW ON SMART CITIES BASED ON IOTTECHNOLOGY
}

\author{
Dinesh Kumar Prajapat \\ Final year student, EE, Arya Institute of Engineering Technology and Management \\ Rahul Chopra \\ Final year student, EE, Arya Institute of Engineering Technology and Management
}

\begin{abstract}
In an IOT based smart city various component like smart water supply management, traffic light control, street lightning system and many more systems are make a city to a smart city. In a smart city allthe necessary facilities such as transportation, water, energy and security etc. related issue can be solving in easy way and the community and people provide a healthy and safety environment.
\end{abstract}

The world is moving forward at a fast with increasing technology in recent time. Thus, a lot of safety issues in all parts of world. So, in this paper mainly focus to provide a well deserved life of all the persons living in the cities. Generally the smart cities definition depends on geographical, environmental andeconomical.

\section{INTRODUCTION}

A smart city is focused on providing the advanced and a developed city. That we will provide an effective water supply system advanced traffic light control system, a well maintained publictransportation that overcome the problems face in normal city [1].

The IOT is similar to the world where worldis fully interconnected each country that's IOT is a combination of various devices that is computer, sensor and many more equipments. Than the aim of smart city can be obtained through IOT that mean by using IOT technology we can develop smart cities at a low cost and high efficiency. As urban population density, Infrastructures are rapidly growing service need to provide the necessities of life.

Smart city may be recognized by various ways. Use of information and communication technology (ICT) for transformation of human life and working environment in that particular region [9].

\section{SMART CITIES: TECHNOLOGIES}

The required components that make up the IOT based smart city landscape followed by the technologies that enable these domains to exist in terms of architectures utilized; networking technologies used as well as the artificial algorithms deployed in IOT based smart city systems.

In contrast to the works of [3], we provide a detailed overview of the different core units and the technologies used in smart city implementations as shown in figure [3].

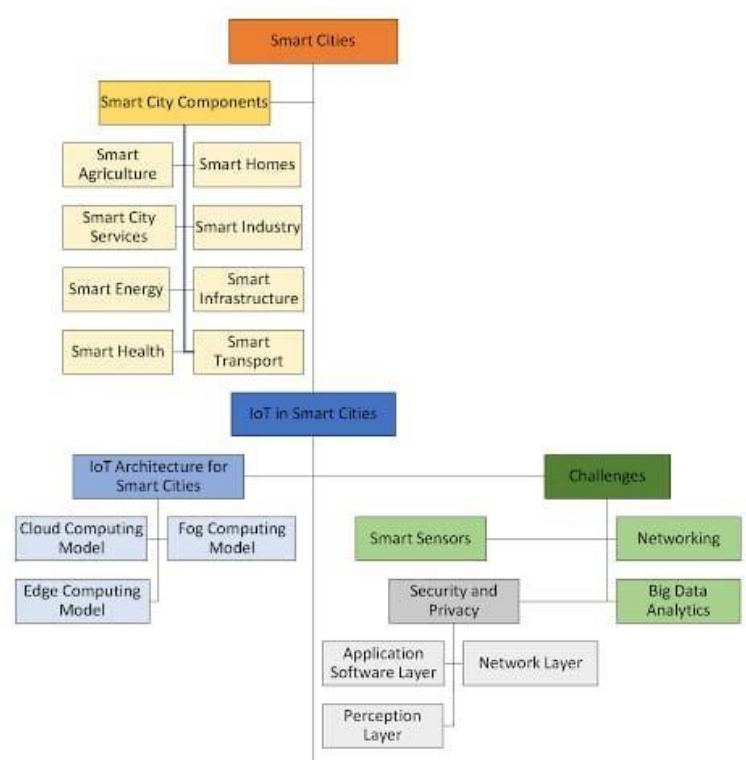

Fig.1: Block diagram of IOT in smart cities

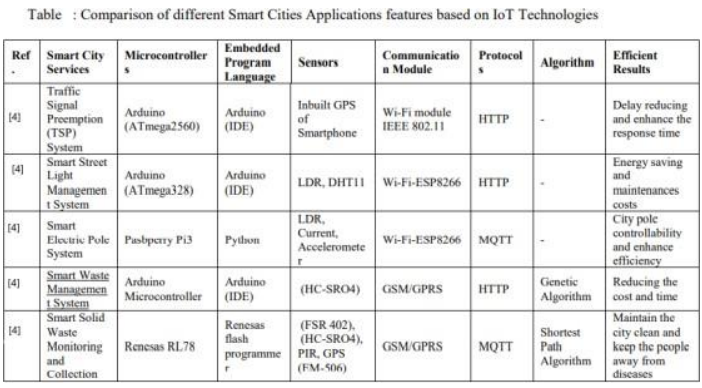



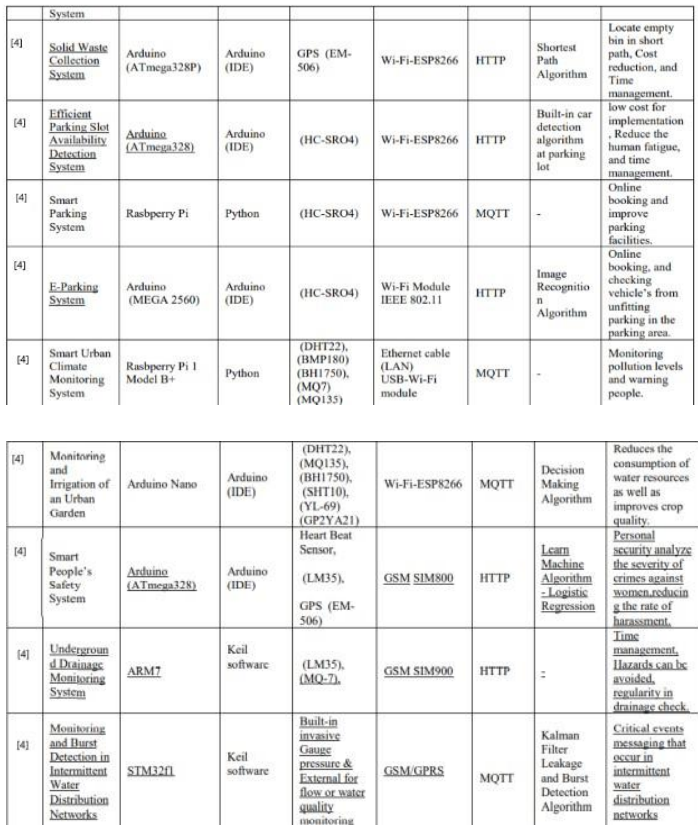

Table shows the type of applications micro controllers, software, sensors, communication modules and other field [4].

\section{SMART CITY APPLICATIONS}

\section{SMART WATER SUPPLY SYSTEM}

Smart water supply is essential factor of smart city in which our main aim to provide a clean and drinking water to the living people of this city. Water is importantfactor to the each person to survival of life.

A water supply system based on pipeline and pump station monitoring with the help of data sciences and IOT.[1]

\section{STREET LIGHTNING CONTROL SYSTEM}

IOT based street light allows supervisors to regulate street lights through wireless connections with a fall resist or fail safe nature that means even in a worst condition our solution falls the lights can still work normally without any interrupt. "These lights embedded [1] with sensors which responds according to surroundings light conditions or brightness i.e. in foggy conditions sensors would turn the light on even if it is 12 of noon".

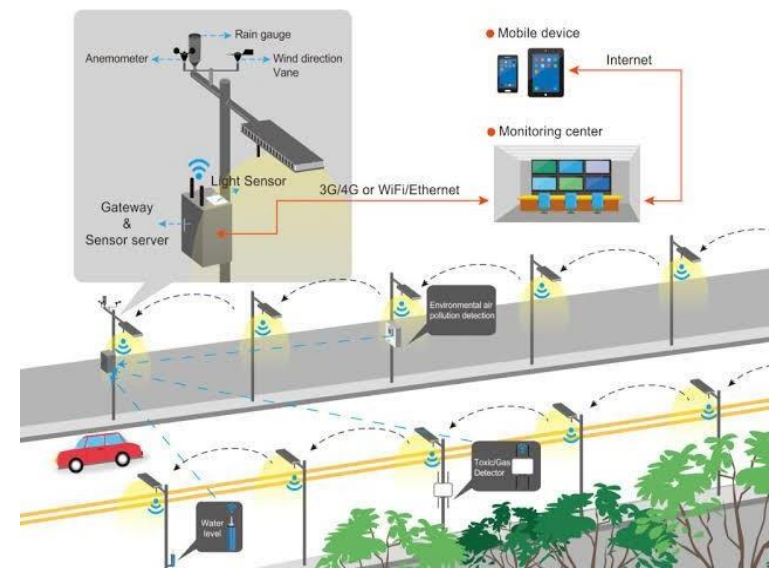

Fig: Smart street lightning control system

\section{TRAFFIC SIGNAL SYSTEM}

Now a day's congestion in traffic is a big problem of a smart city so that the traffic signal issue can be resolve by using micro controller. This signal system is used to reduce traffic problems. In this system contains transmitter and either side of road whenever a vehicle passes on road between IR transmitter and receiver than the IR system get activated which is control by micro controller than after this system count the number of vehicles passing on the road. This data is store in memory, and then micro controller should take decision and update the traffic light delay as a result, overcome the traffic congestion. [5]

\section{NOISE MONITORINGS}

Noise can be seen as a form of aural pollutionas much as carbon oxide (CO) in air so, acity IOT can offer a noise monitoring service to measure the amount of noise produced at any given hour in the places that adopt the service and also be used sound detection algorithms to overcome the noise pollution inthe city.

\section{INTELLIGENT PARKING}

Smart parking system makes a smart city more effective. Thus, by enabling smart parking you can track located in the departure city and the arrival of a variety of different parking vehicles. So the number of each field of smart vehicles parking should be designed.

\section{SMART HOME}

Data generated by the sensors can be used tomonitor 
the intelligent home. For example, an innovative demand response or the function may be implemented by monitoring pollution, contamination and if it exceeds a critical limit, the client can be warned [6].

\section{IOT BASED SMART CITIES}

In the world various countries make IOT based smart cities and give an advance level of smart city vision as shown in fig [7].

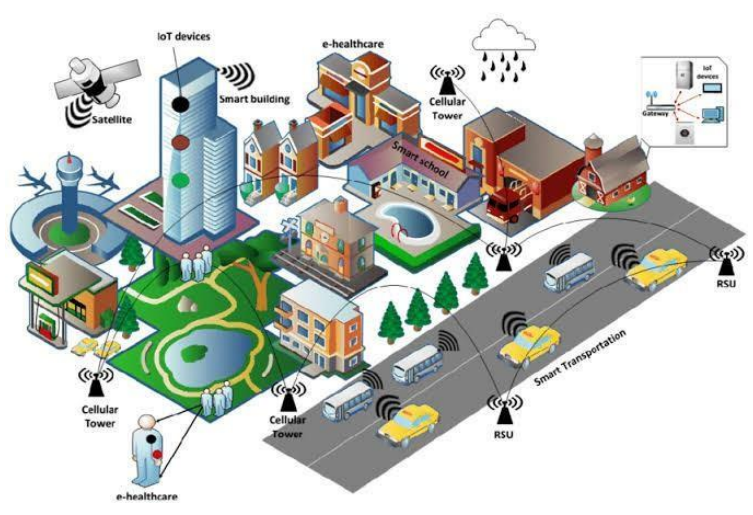

Fig: An assumption of IOT model

\begin{tabular}{|c|c|c|c|}
\hline City & Country & Solutions & $\begin{array}{l}\text { Major } \\
\text { partners }\end{array}$ \\
\hline Busan & $\begin{array}{l}\text { South } \\
\text { Korea }\end{array}$ & $\begin{array}{l}\text { Safety service } \\
\text { forchildren } \\
\text { /elderly, } \\
\text { drone } \\
\text { based } \\
\text { smart } \\
\text { marine, } \\
\text { smart } \\
\text { parking }\end{array}$ & $\begin{array}{l}\text { Busan } \\
\text { government, } \\
\text { Cisco,ETRI, } \\
\text { KETI, SK } \\
\text { telecom, } \\
\text { KT }\end{array}$ \\
\hline Santander & Spain & $\begin{array}{l}\text { Smart } \\
\text { metering of } \\
\text { temperature, } \\
\text { traffic } \\
\text { intensity, } \\
\text { humidity, } \\
\text { transportation } \\
\quad \text { plans, } \\
\text { water needs, } \\
\text { etc. }\end{array}$ & $\begin{array}{l}\text { Ericsson, } \\
\text { Telefonica, } \\
\text { Telefonica } \\
\text { I+D }\end{array}$ \\
\hline Chicago & USA & $\begin{array}{l}\text { Smart grid, } \\
\text { smart living, } \\
\text { emergency } \\
\text { alerting, } \\
\text { reduced } \\
\text { crimes }\end{array}$ & $\begin{array}{l}\text { Cisco, } \\
\text { IBM, } \\
\text { Chicago } \\
\text { government }\end{array}$ \\
\hline
\end{tabular}

\begin{tabular}{|l|l|l|l|}
\hline $\begin{array}{l}\text { Milton } \\
\text { Keynes }\end{array}$ & UK & $\begin{array}{l}\text { Smart } \\
\text { transportation, } \\
\text { reduced } \\
\text { alerting, }\end{array}$ & $\begin{array}{l}\text { Milton } \\
\text { Keynes } \\
\text { council, } \\
\text { Samsung, } \\
\text { Huawei, }\end{array}$ \\
\hline
\end{tabular}

\section{CONCLUSIONS}

In this review paper we have generally focus on the IOT for smart cities and its role. In IOT based smart city various component like water supply and management system, street lightning system, public transportation, traffic control system, smart home and many more features make a city smart city. IOT just a technology which is developed a smart city with low cost and maximum efficiency and provide a healthy and safety environment of the citizens.

\section{REFERENCES:}

1. Prateek gurani, Mohit Sharma, Shreya nigam, Natasha soni, Krishan Kumar "IOT Smart city: Introduction and challenges", International Journal of Recent Technology and Engineering (IJRTE), ISSN: 2277-3878, volume-8 ISSUE-3, September 2019.

2. You Arroub, Bassma zahi, Essaid sabir and Mohamed sadik, NEST Research group, LRI Lab, ENSEM, Hassan 2 University of Casablanca, Morocco, "A literature Review on Smart cities: Paradigms, Opportunities and open problems", () 2016 IEEE.

3. Syed, AS; Sierra-Sosa, D; Kumar, A; Elmaghraby, A.IOT in Smart cities: A Survey of Technologies, Practices and Challenges. Smart cities 2021, 4, 429-475. https://doi.org/10.3390/smartcities4020024.

4. Saleem Ibraheem Saleem, Subhi R.m. Zeebaree, Diyar Qadar Zeebaree, Adnan mohsin Abdula Zeez. "Building smart cities Applications based on IOT Technologies: A Review", TRKU, ISSN: 04532198, Volume 62, ISSUE 03, and April, 2020.

5. Suita C, Asha priya B, Lavanya S, "Need of Internet of things for Smart cities", International Journal of Trend in Scientific

Research and Development (IJTSRD), Volume: 3, ISSUE: 4, may-jun 2019 Available online: www.ijtsrd.com e- ISSN: 2456-6470.

6. Mukesh Kumawat, Mr. Durgesh Kumar, Dr. Garima mathur, "IOT Based Smart cities", International Journal of Trend in Scientific 
Research and Development (IJTSRD), Volume: 3, ISSUE: 3, mar-apr 2019.

7. Yasir Mehmood, Farhan Ahmad, Ibrar Yaqoob, Asma Adnane, Muhammad Imran, and Sghaier Guizani, "Internet-of-Things Based Smart cities: Recent Advances and challenges", DOI:

10.1109. MCOM.2017.1600514, IEEE Communications Magazine September 2017.

8. Gaurav sarin "Developing smart cities using IOT: An Empirical Study." https://www.researchgate.net/publication/30 5689751, march2016.

9. Ms. Rashmi dongre, Dr. Meera Deshmukh, "IOT and smart city- Transformation of cities through IOT", International Journal of applied Engineering Research ISSN 0973-4562 volume 14, Number 7, 2019.

10. Devi kala Rathinam. D, Sherin. J, Santhiya Grace. A, "IOT Based smart Environment and its Applications", International Journal of Trend in Scientific Research and development (IJTSRD), ISSN No: 2456- 6470, www.ijtsrd.com,volume -2, ISSUE-4, may-jun 2018.

11. H.Samih, smart cities and internet of things, Journal of Information Technology case and Application Research, 21:1, 3-12, 2019, DoI:10.1080/15228053.2019.1587572.

12. Priyanka N, Aditya vasisht, "smart cities", International Journal of Engineering science Invention, ISSN: 2319-6734, Volume 4, ISSUE 9, September 2015.

13. Andrea zanella, Lorenzo vangelista, "Internet of things for smart cities", IEEE, Vol.1, No.1, feb.2014.

14. S. Kumari, S. Kulkarni, N. Patil and V. Deshpande, "An Internet of things based Implementation of smart digital city prototype", IEEE, 2020, PP.176-184, doi: 10.1109/ICSSIT 48917.2020.9214157.

15. N.Dlodlo, O.Gcaba and A.Smith, "Internet of things technologies in smart cities", IEEE, 2016, PP-1-7, doi: 10.1109/ISTAFRICA. 2016.7530575. 